\title{
Estimating Aboveground Net Primary Production in Grasslands: A Comparison of Nondestructive Methods
}

\author{
Kerry M. Byrne, ${ }^{1}$ William K. Lauenroth, ${ }^{2}$ Peter B. Adler, ${ }^{3}$ and Christine M. Byrne ${ }^{4}$ \\ Authors are ${ }^{1}$ Graduate Student, Graduate Degree Program in Ecology, Colorado State University, Fort Collins, CO 80523, USA; ${ }^{2}$ Professor, Department \\ of Botany, University of Wyoming, Laramie, WY 82071, USA; ${ }^{3}$ Assistant Professor, Department of Wildland Resources and the Ecology Center, Utah \\ State University, Logan, UT 84322, USA; and ${ }^{4}$ Undergraduate Student, Department of Environmental Science, Policy, and Management, University of \\ California, Berkeley, CA 94720, USA.
}

\begin{abstract}
Aboveground net primary production (ANPP) is an important ecosystem property that is affected by environmental variability. ANPP in grasslands is typically measured by clipping peak live plant material. However, this method is time intensive (and therefore expensive), making it difficult to capture spatial and temporal variability. Additionally, it is impractical to use a destructive method to estimate ANPP in long-term, permanent plots. Thus, many double-sampling techniques have been developed to reduce costs and increase sample size. The objective of our study was to assess the accuracy and precision of nondestructive techniques to estimate ANPP as supplements to the traditional method of peak biomass harvest at two grassland sites. We harvested biomass and compared estimates from the same plots to 1) canopy interception using a point frame, 2) green cover estimates derived from a digital camera, and 3) reflectance measurements using a handheld radiometer. We calculated the optimum allocation of sampling effort to direct and indirect methods to minimize sampling cost yet achieve a desired precision. We found that the point frame technique explained the highest proportion of the variability in biomass at both sites $\left(R^{2}=0.91\right.$, $0.90)$. However, our cost-optimization analysis revealed that the radiometer technique, although less accurate $\left(R^{2}=0.38,0.51\right)$, could achieve a desired precision for lower labor costs than the point frame. The radiometer and point frame methods will be a useful tool for grassland ecologists and rangeland managers who desire fast, nondestructive estimates of ANPP.
\end{abstract}

\section{Resumen}

La producción primaria neta PPN es una propiedad importante en el ecosistema que es afectada por la variabilidad medioambiental. La PPN en pastizales se mide normalmente por medio de cortes de la parte viva de la planta. Sin embargo, este método consume mucho tiempo (y es caro) haciendo difícil estimar la variabilidad espacial y temporal. Además, es impráctico usar métodos destructivos para estimar la PPN en el largo plazo en parcelas permanentes. Por esto, técnicas de doble muestreo se han desarrollado para reducir el costo y aumentar el tamaño de muestra. El objetivo de nuestro estudio fue evaluar la eficacia y eficiencia de técnicas no destructivas para estimar la PPN como complementos del método tradicional de cosecha de la biomasa en dos tipos de pastizales. Se cosecho la biomasa y se comparo las estimaciones de las mismas parcelas para 1) intercepción del dosel con el método del punto, 2) estimación de la cubierta verde derivada de una cámara digital, y 3) medidas de reflejo usando un radiómetro manual. Calculamos la ubicación óptima de esfuerzo de muestreo por métodos directos e indirectos para reducir el costo de muestreo y lograr la precisión deseada. Encontramos que la técnica del punto explico la mayor proporción de la variabilidad de biomasa en ambos sitios $\left(R^{2}=0.91,0.90\right)$. Sin embargo, el análisis optimización-costo revelo que la técnica del radiómetro aunque menos precisa $\left(R^{2}=0.38,0.51\right)$ podría lograr la precisión deseada con menor costo que el punto. Los métodos del radiómetro y el punto serán herramientas útiles para ecólogos y manejadores de pastizales que requieren de estimaciones de PPN rápidas y no destructivas.

Key Words: cost optimization, double sampling, handheld radiometer, mixed grass prairie, point frame, shortgrass steppe

\section{INTRODUCTION}

Aboveground net primary production (ANPP) is an important attribute of ecosystems, and quantifying ANPP is a frequent goal of basic and applied ecology (Sala and Austin 2000). Estimates of ANPP are necessary to understand the global carbon balance and trophic interactions. McNaughton et al. (1989) proposed that net primary production can be used as

Research was supported by grants from the NSF (DEB 0217631 SGS LTER and DEB 0823405) and the Utah Agricultural Experiment Station (to P.B.A.).

Correspondence: Kerry Byrne, Graduate Degree Program in Ecology, Colorado State University, Fort Collins, CO 80523, USA. Email: kmbyrne@rams.colostate.edu

Manuscript received 27 August 2010; manuscript accepted 20 April 2011. an integrative ecosystem variable because it both reflects and influences other trophic levels. From an applied perspective, estimates of ANPP are used to determine forage availability and stocking rates for livestock and managed wildlife populations in rangelands, as well as wood yield in forests.

ANPP is the amount of aboveground plant biomass or carbon accumulated over a specific time period. Singh et al. (1975) reviewed different methods of harvesting standing biomass to estimate ANPP. The simplest and most common technique in grasslands is to clip green and current year dead material of grasses and forbs and current year green production (excluding woody tissue) for dwarf shrubs at peak biomass. This method has been shown to produce estimates with low uncertainty (Lauenroth et al. 2006) and 
close to the true value in model simulations (Lauenroth et al. 1986).

Although biomass harvesting provides accurate estimates of ANPP, it is time intensive (and therefore expensive), making it difficult to capture spatial and temporal variability. Additionally, it is impractical to use a destructive method to estimate ANPP in long-term, permanent plots. Thus, many doublesampling techniques have been developed to reduce costs and increase sample size. Common double-sampling techniques include capacitance meter (Fletcher and Robinson 1956; Vickery et al. 1980), handheld radiometers, indices such as the normalized difference vegetation index (NDVI; Tucker 1975; Asrar et al. 1985; Aase 1987), analysis of digital photographs (Paruelo et al. 2000; Tomasel et al. 2001), and estimates of canopy cover (Jonasson 1988; Frank and McNaughton 1990).

The objective of our study was to assess the accuracy and precision of nondestructive techniques to estimate ANPP as supplements to the traditional method of peak biomass harvest. In two grassland sites, we harvested biomass and compared estimates from the same plots to 1) canopy interception using a point frame, 2) green cover estimates derived from a digital camera, and 3) reflectance measurements using a handheld radiometer. We calculated the optimum allocation of sampling effort to direct (harvest) and indirect (canopy interception, digital camera, radiometer) methods to minimize sampling cost yet achieve a desired precision.

\section{METHODS}

\section{Study Sites}

We conducted our research at two locations along the precipitation gradient of the central grassland region in the United States. The first site is located on the semiarid shortgrass steppe at the Central Plains Experimental Range (CPER), $60 \mathrm{~km}$ northeast of Fort Collins, Colorado (lat $40^{\circ} 49^{\prime} \mathrm{N}$, long $\left.104^{\circ} 46^{\prime} \mathrm{W}\right)$. The CPER is administered by the USDA Agricultural Research Service and is also the Shortgrass Steppe Long Term Ecological Research site. Mean annual precipitation is $341 \mathrm{~mm}$, and mean annual temperature is $8.2^{\circ} \mathrm{C}$. The plant community is dominated by typical upland vegetation, including the short-stature $\mathrm{C}_{4}$ grasses blue grama (Boutelona gracilis Willd. ex Kunth Lag. ex Griffiths) and buffalograss (Bouteloua dactyloides [Nutt.] J. T. Columbus), the forb scarlet globemallow (Sphaeralcea coccinea [Nutt.] Rydb.), the cactus plains pricklypear (Opuntia polyacantha Haw.), and the dwarf shrubs prairie sagewort (Artemisia frigida Willd.), spreading buckwheat (Eriogonum effusum Nutt), rubber rabbitbrush (Chrysothamnus nauseosus [Pall. ex Pursh] Britton), and broom snakeweed (Gutierrezia sarothrae [Pursh] Britton \& Rusby; Lauenroth 2008), and patches of bare ground are prevalent (Fig. 1A). Cattle grazing is excluded at the study site.

The second site is located in the subhumid southern mixed grass prairie, at Fort Hays State University College Farm, in west-central Kansas, $3 \mathrm{~km}$ west of Hays (lat $38^{\circ} 52^{\prime} \mathrm{N}$, long $\left.99^{\circ} 23^{\prime}\right)$. Mean annual precipitation near Hays is $583 \mathrm{~mm}$, and mean annual temperature is $12.1^{\circ} \mathrm{C}$. The plant community includes a mixture of tall-, mid-, and short-stature grasses, predominantly $\mathrm{C}_{4}$ species (Fig. 1B). Bare ground is much less
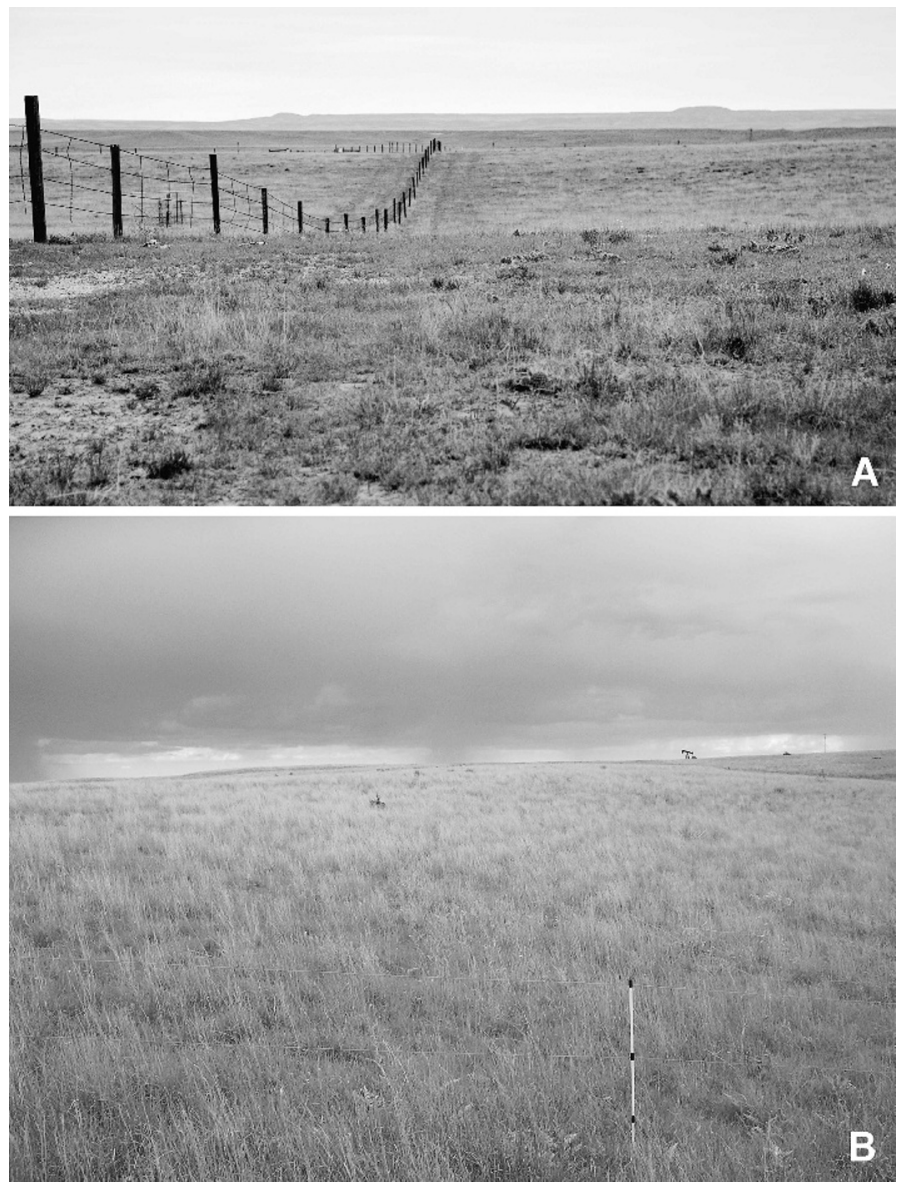

Figure 1. A, Typical shortgrass vegetation at the Central Plains Experimental Range, Colorado, including the dominant grass Bouteloua gracilis, Opuntia polycantha cactus, and dwarf shrub Artemisia frigida. (Photo by Sallie Sprague.) B, Typical mixed grass vegetation near Hays, Kansas, including dominant grasses Schizachyrium scoparium and Andropogon gerardii and dwarf shrub Gutierrezia sarothrae.

prevalent than on the shortgrass steppe. The most common tallstature grass is big bluestem (Andropogon gerardii Vitman). Common midstature grasses include little bluestem (Schizachyrium scoparium [Michx.] Nash) and sideoats grama (Bouteloua curtipendula [Michx.] Torr). Common shortstature grasses include blue grama and hairy grama (Bouteloua hirsuta Lag). Broom snakeweed is the most common dwarf shrub (Albertson and Tomanek 1965). Cattle grazing is excluded at the study site.

\section{Experimental Design and Data Analysis}

Fifteen $0.5 \mathrm{~m}^{2}$ plots were selected at the CPER, and $140.5 \mathrm{~m}^{2}$ plots were selected at Hays. We chose plots at each site to contain a range of total plant cover and a range of cover by functional groups. We performed each nondestructive method on every plot at peak biomass (20-26 July 2009 in Hays and 28 July-4 August 2009 at the CPER). Following nondestructive sampling, we clipped green and recent dead material of grasses and forbs and current year's green production (excluding woody tissue) for dwarf shrubs. Since the $0.25 \mathrm{~m}^{2}$ circular sample area used for the radiometer method fit inside each $0.5 \mathrm{~m}^{2}$ rectangular quadrat used for the other methods, we first 
clipped biomass inside the circular quadrat, then clipped biomass within the rectangular quadrat but outside of the circular sample area. Biomass was clipped at the soil surface, separated by functional group, and placed in paper bags. Samples were dried for at least $48 \mathrm{~h}$ at $55^{\circ} \mathrm{C}$ then weighed. We used total biomass data as an estimate of ANPP (Lauenroth et al. 1986, 2006).

We constructed four models based on a priori hypotheses using multiple and simple linear regressions to relate predictor variables to biomass. We performed a residual analysis on all models and removed any data points that fell more than $3 \mathrm{SD}$ from the regression line. We then used Akaike's information criterion (with small sample size correction; AICc) for model selection. We conducted all data analysis in $\mathrm{R} 2.10 .0$ ( $\mathrm{R}$ Development Core Team 2009).

\section{Nondestructive Sampling Methods}

Point Frame. Previous research has shown good results relating canopy interception by the point-intercept method to biomass in other grass-dominated ecosystems (Jonasson 1988; Frank and McNaughton 1990). We used a $62 \times 80 \mathrm{~cm}$ quadrat with 50 equally spaced points inside as our point frame. We passed a pin perpendicular to the soil surface through each of the points and recorded the number of times the pin hit any green vegetation, dead standing vegetation, litter, or bare ground. Green hits were separated into three functional groups: graminoids, forbs, and dwarf shrubs.

Point Frame $\times$ Height. We used the data from the point frame method, but also included average height of vegetation within the frame. We thought that including a metric of canopy height in our point frame model would improve its predictive capability. We calculated average height in each quadrat from the heights of the first hit at each of the 50 points within the point frame.

Digital Camera. We took digital images of each $0.5 \mathrm{~m}^{2}$ plot from $\sim 1.25 \mathrm{~m}$ elevation with a First Growth digital canopy camera (Decagon Devices 2004) using the set protocol detailed by the manufacturer. The camera quantifies percent green cover in the field with an internal processor based on the ratio of green pixels to total pixels. All images were taken between 1100 and 1400 hours on clear days to minimize shadow effects.

Radiometer. We measured actual reflectance with a Skye Instruments SKR 1850 4-Channel Light Sensor (http://www. skyeinstruments.com). The radiometer was mounted on a telescoping boom at a $1.25 \mathrm{~m}$ elevation over each plot, which the manufacturer calculated as the distance above the ground necessary to achieve a $0.25 \mathrm{~m}^{2}$ circular sampling area. We took measurements between 1100 and 1400 hours on clear days. We did not use a standard reflectance panel, which could have improved our results. We calculated a greenness index (GI) as follows using two of the four light bands:

$$
\mathrm{GI}=\frac{(\mathrm{NIR}-\mathrm{RED})}{(\mathrm{NIR}+\mathrm{RED})},
$$

where RED is reflectance in the red band $(570-680 \mu \mathrm{m})$, and NIR is reflectance in the near-infrared band $(725-1000 \mu \mathrm{m})$.
This GI is based on the formula for NDVI (Sellers 1987; Sellers et al. 1992), but as we did not measure incident radiation, we could only calculate a GI. The radiometer reports reflectance in a circular area, and the digital camera and point-intercept frame are both rectangular. It was necessary to rescale the response variable (biomass) in order to compare models. We rescaled the response variable so that it had the same mean and standard deviation as the rectangular scope using the following formula:

$$
\left(\frac{Y_{c}-\bar{c}}{s_{c}}\right) s_{r}+\bar{s}=Y_{\text {cnew }},
$$

where $Y_{c}$ is the amount of biomass in the circular quadrat, $\bar{c}$ is the mean biomass value of the circular quadrat, $s_{c}$ is the standard deviation of the circular quadrat, $s_{r}$ is the standard deviation of the rectangular quadrat, and $\bar{s}$ is the mean value of the rectangular quadrat.

\section{Optimization Analysis}

To determine the optimal sampling efforts for each site, we asked two separate but related questions: 1) what is the optimal investment in direct and indirect sampling for each indirect method and 2) how does total sampling cost (as determined by question 1) vary across indirect methods given desired precision levels. In the field, we estimated the average time investment (in minutes) to perform the direct and each of the indirect sampling methods at each site. To answer our first question, we calculated the sampling ratio for each method at each site to determine the optimal ratio of indirect to direct samples. Cochran (1963) and others have shown that one can calculate the optimal allocation ratio of sampling efforts for indirect and direct methods to minimize the variance of the estimate (in our case, an estimate of biomass) for a given cost. If, for a given sampling cost, the variance of the estimated biomass using the indirect method (with larger sample size) is smaller than the variance that can be attained from the direct method (with smaller sample size), then it is less expensive to take a combination of direct and indirect samples in order to minimize labor cost yet maximize precision (see appendix for formula). To answer our second question, we used the methods describe in Ahmed and Bonham (1982) to calculate for each site the optimal sampling allocation required in each phase (direct and indirect sampling) in order to achieve a desired relative precision of the biomass estimate. We defined relative precision based on half the width of the $95 \%$ confidence interval $( \pm \sim 2 \mathrm{SD})$, as a percentage of the estimate itself. For example, a $10 \%$ desired precision for a biomass estimate of 100 would mean that the $95 \%$ confidence interval for the biomass estimate would be $100 \pm 10$. We used relative precision levels of $10-50 \%$ in increments of $5 \%$. We defined relative precision in terms of the $95 \%$ confidence interval, rather than in terms of the coefficient of variation $(\mathrm{CV}=\mathrm{SD} /$ estimate) because the $95 \%$ confidence interval is the more common method of specifying uncertainty. Finally, we calculated the total cost of double sampling by multiplying the time investment to perform the direct and indirect sampling efforts and the number of samples for each method (see appendix for formula). 
Table 1. Model selection results for biomass prediction at the shortgrass steppe. Models are ranked by AIC $c$. $\triangle \mathrm{AIC} c$ is the difference in AIC $c$ units from the highest-ranking model. $R^{2}$ values are shown. ${ }^{*}$ Signifies models or parameters with $P<0.05,{ }^{*}$ signifies models or parameters with $P<0.01$, and ${ }^{* * *}$ signifies models or parameters with $P<0.0001$.

\begin{tabular}{|c|c|c|c|c|}
\hline Method & Model & $\operatorname{AICC}$ & $\triangle \mathrm{AICc}$ & $R^{2}$ \\
\hline Point frame $\times$ height & $\begin{array}{l}0.059 \mathrm{x}_{F}-0.11 \mathrm{x}_{G}-1.40 \mathrm{x}_{S}+3.50 \mathrm{x}_{H^{+}} \\
0.021 \mathrm{x}_{H F}-0.003 \mathrm{x}_{H G}+0.056 \mathrm{x}_{H S}+53.53^{1,2}\end{array}$ & 123.72 & 0 & $0.91^{* *}$ \\
\hline Point frame (functional group) & $1.25 x_{F}^{*}+0.32 x_{G}+0.73 x_{S}^{*}+29.7^{1}$ & 137.82 & 14.10 & $0.55^{\star}$ \\
\hline Point frame (total hits) & $0.37 \mathrm{x}_{\text {TOT }^{*}}{ }^{*} 37.7^{3}$ & 140.13 & 16.41 & $0.29^{\star}$ \\
\hline Radiometer & $254.5 \mathrm{x}_{G 1}{ }^{\star}-34.9^{4}$ & 141.07 & 17.35 & $0.38^{\star}$ \\
\hline Digital camera & $142.8 \mathrm{x}_{\text {CAM }}+86.6^{\star 5}$ & - & - & 0.10 \\
\hline
\end{tabular}

${ }^{1} \mathrm{X}_{F}, \mathrm{X}_{G}, \mathrm{X}_{S}=$ total number of hits by forbs $\left(\mathrm{X}_{F}\right)$, graminoids $\left(\mathrm{x}_{G}\right)$, and dwarf shrubs $\left(\mathrm{x}_{S}\right)$.

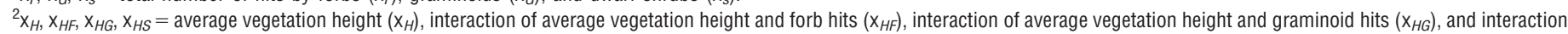
of average vegetation height and dwarf shrub hits $\left(\mathrm{x}_{H S}\right)$.

${ }^{3} \mathrm{X}_{T O T}=$ total number of vegetation hits.

${ }^{4} X_{G I}=$ greenness index as calculated by radiometer.

${ }^{5} \mathrm{x}_{\text {CAM }}=$ percent green cover.

\section{RESULTS}

\section{Point Frame (Total Hits)}

The point frame data of total vegetation hits did not explain a large proportion of the variability in biomass at the shortgrass steppe but did at the mixed grass prairie. For the shortgrass steppe, the total number of hits was a significant explanatory variable $(P<0.05)$ but explained only $20 \%$ of the variability in biomass (Table 1). For the mixed grass prairie, the total number of hits was a significant explanatory variable $(P<0.0001)$ and explained $85 \%$ of the variability in biomass (Table 2).

\section{Point Frame (Functional Group)}

The functional group data explained a large proportion of the variability in biomass at both sites. For the shortgrass steppe, the number of grass hits and the number of forb hits were each significant explanatory variables $(P<0.05)$, and the model explained $55 \%$ of the variability in biomass (Table 1 ). For the mixed grass prairie, we removed one outlier data point after our initial analysis, which improved model performance. The number of grass hits was the only individual variable that was significant $(P<0.0001)$, and the model explained $89 \%$ of the variability in biomass (Table 2 ).

\section{Point Frame $\times$ Height}

Including average height of first hit in the functional group model greatly improved its explanatory power at the shortgrass steppe and slightly improved its explanatory power at the mixed grass prairie. No individual parameters were significant at either site, but explanatory power of the models increased to 91\% (Table 1) at the shortgrass steppe and $90 \%$ for the mixed grass prairie (Table 2).

\section{Digital Camera}

Green cover estimated by the digital canopy camera did not explain a large proportion of the variability in biomass at either site. The model explained $10 \%$ of the variability in biomass on the shortgrass steppe (Table 1 ) and $21 \%$ of the variability in biomass on the mixed grass prairie site (Table 2). We did not include the camera method in our comparison of AIC $c$ values at the shortgrass steppe because we removed an outlier data point. We did not include the camera method in our comparison of $\mathrm{AIC} c$ values at Hays as there were two missing green cover estimates.

\section{Radiometer}

The radiometer data explained $38 \%$ of the variability in biomass at the shortgrass steppe and $51 \%$ of the variability in

Table 2. Model selection results for biomass prediction at the mixed grass prairie. Models are ranked by AIC $c . \triangle A I C c$ is the difference in AIC $c$ units from the highest ranking model. $R^{2}$ values are shown. ${ }^{*}$ Signifies models or parameters with $P<0.05$, ** signifies models or parameters with $P<0.01$, and ${ }^{* *}$ signifies models or parameters with $P<0.0001$.

\begin{tabular}{|c|c|c|c|c|}
\hline Method & Model & $\operatorname{AICC}$ & $\triangle \mathrm{AICC}$ & $R^{2}$ \\
\hline Point frame $\times$ height & $\begin{array}{l}14.65 \mathrm{x}_{F}+3.54 \mathrm{x}_{G}-1.63 \mathrm{x}_{S}+17.24 \mathrm{x}_{H}- \\
0.920 \mathrm{x}_{H F}-0.111 \mathrm{x}_{H G}-0.0094 \mathrm{x}_{H S}-268.1^{1,2}\end{array}$ & 116.30 & 0 & $0.90^{*}$ \\
\hline Point frame (total hits) & $1.34 \mathrm{x}_{\text {TOT }}{ }^{\star \star *}-25.15^{3}$ & 116.89 & 0.59 & $0.85^{\star \star \star}$ \\
\hline Point frame (functional group) & $1.42 x_{F}+1.41 x_{G}{ }^{* * *}-0.381 x_{s}-23.4^{1}$ & 117.00 & 0.70 & $0.89^{* *}$ \\
\hline Radiometer & $431.1 \mathrm{X}_{G I^{*}}-176.8^{4}$ & 132.11 & 15.81 & $0.51^{* \star}$ \\
\hline Digital camera & $283.1 \mathrm{x}_{C A M}+29.8^{5}$ & - & - & 0.21 \\
\hline
\end{tabular}

${ }^{1} \mathrm{X}_{F}, \mathrm{X}_{G}, \mathrm{X}_{S}=$ total number of hits by forbs $\left(\mathrm{x}_{F}\right)$, graminoids $\left(\mathrm{x}_{G}\right)$, and dwarf shrubs $\left(\mathrm{x}_{S}\right)$.

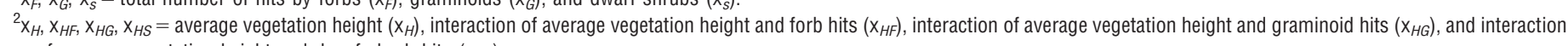
of average vegetation height and dwarf shrub hits $\left(\mathrm{x}_{H S}\right)$.

${ }^{3} x_{T O T}=$ total number of vegetation hits.

${ }^{4} X_{G I}=$ greenness index as calculated by radiometer.

${ }^{5} \mathrm{X}_{\text {CAM }}=$ percent green cover. 
Table 3. Estimated sampling costs for direct and indirect sampling methods and optimal sampling ratio for the shortgrass steppe site.

\begin{tabular}{lccc}
\hline \multicolumn{1}{c}{ Method } & Direct sampling cost $(\mathrm{min})$ & Indirect sampling cost (min) & Calculated ratio (indirect/direct) \\
\hline Point frame (total hits) & 90 & 40 & 0.96 \\
Point frame (functional group) & 90 & 45 & 1.56 \\
Radiometer & 90 & 5 & 3.32 \\
Point frame $\times$ height & 90 & 45 & 4.50 \\
\hline
\end{tabular}

biomass at the mixed grass prairie. For the shortgrass steppe, greenness was a significant explanatory variable $(P<0.05$; Table 1). For the mixed grass prairie site, greenness was also a significant explanatory variable $(P<0.01$; Table 2$)$.

\section{Optimization Analysis}

It took approximately $90 \mathrm{~min}$ to clip each $0.5 \mathrm{~m}^{2}$ plot on the shortgrass steppe. The per plot time estimator for the indirect methods ranged from a minimum of $5 \mathrm{~min}$ for the radiometer method to a maximum of $45 \mathrm{~min}$ for the point frame data that included average vegetation height. The ratio of indirect to direct sampling efforts with minimum variance ranged from 0.96 to 4.50 (Table 3 ).

On the mixed grass prairie, direct sampling took approximately twice as long as it did on the shortgrass steppe, because of the increase in vegetation cover. Clipping each $0.5 \mathrm{~m}^{2}$ plot took approximately $180 \mathrm{~min}$. The per plot times for the indirect methods ranged from a minimum of $5 \mathrm{~min}$ for the radiometer method to a maximum of $60 \mathrm{~min}$ for the point frame model that included average vegetation height. The ratio of indirect to direct sampling efforts with minimum variance ranged from 4.52 to 6.12 (Table 4 ).

We found that at both sites, the radiometer method always required the minimum labor costs in order to achieve a desired relative precision, and the point frame $\times$ height method was always the second most cost effective (Tables 5 and 6).

\section{DISCUSSION}

Our results demonstrate that not all double-sampling methods accurately predict biomass at our two study sites. Our digital camera explained very little of the variability in biomass at both sites $\left(R^{2}=0.10\right.$ and 0.21$)$. Another study reported that the internal greenness calculations of the First Growth camera seemed to increase systematically due to continual use of the camera and concluded that the camera was not an effective tool to use for estimating green cover (Canton et al. 2004). However, others have found that digital cameras can accurately predict biomass. Paruelo et al. (2000) and Tomasel et al. (2001) were able to accurately predict biomass, and Przeszlowska et al. (2009) were able to accurately predict green cover on the shortgrass steppe using percentage green pixels from film and digital photographs taken three times throughout the growing season. Using a very different method, Limb et al. (2007) were able to estimate vertical standing biomass using a simple binary analysis of black and white pixels, which may be a helpful technique for some land managers. In conclusion, digital cameras may be useful in some situations, especially if multiple images are taken throughout the growing season.

Our results were similar to Jonasson (1988) and Frank and McNaughton (1990), who found strong relationships between hits by species or functional group and biomass. It is interesting to note that in the Jonasson (1988) study and in our study, the pins in the frame were positioned perpendicular to the soil surface. Frank and McNaughton (1990) inclined the pins at a $53^{\circ}$ angle, but had similar success. It appears that the angle of inclination for the pin does not matter. However, neither of the other studies included average vegetation height in their models, which we found improved the predictive ability of our models. On the shortgrass steppe, the best model included both average vegetation height and number of hits by each functional group. At the mixed grass prairie site, the point frame $\times$ height model did not greatly improve the $\mathrm{AIC} c$ value nor the amount of variation explained compared to a model based only on the number of hits. This is likely due to the greater heterogeneity in vegetation on the shortgrass steppe. The average plot height varied much more on the shortgrass steppe than on the mixed grass prairie. Plots with taller average vegetation had, on average, greater ANPP (data not shown). Including the height variable on the shortgrass steppe allowed the model to account for the heterogeneity in vegetation height and provide a better prediction of ANPP. Thus, we recommend that vegetation height be included when using the point frame method in grasslands with variable vegetation height.

Our radiometer results are similar to a previous study by Tucker et al. (1975), who found a strong correlation $(r=0.85)$ between reflectance and biomass, and Przeszlowska et al. (2009), who found a strong relationship between reflectance and greenness $\left(R^{2}=0.76\right)$ on the shortgrass steppe. The higher correlation may be a result of our differing sampling procedures: Tucker et al. (1975) selected homogenous plots of blue grama, while we purposefully selected plots with a range of species and plant cover. This heterogeneity may have lead to an overestimation of the number of samples required to achieve a desired precision in our study, as a random sample

Table 4. Estimated sampling costs for direct and indirect sampling methods and optimal sampling ratio for the mixed grass prairie site.

\begin{tabular}{lccc}
\hline \multicolumn{1}{c}{ Method } & Direct sampling cost $(\mathrm{min})$ & Indirect sampling cost (min) & Calculated ratio (indirect/direct) \\
\hline Point frame (total hits) & 180 & 50 & 4.52 \\
Point frame (functional group) & 180 & 60 & 4.93 \\
Radiometer & 180 & 5 & 6.12 \\
Point frame $\times$ height & 180 & 60 & 5.20 \\
\hline
\end{tabular}


Table 5. Number of direct and indirect samples required and labor cost (in hours) to achieve a desired relative precision for the shortgrass steppe site. For each desired precision, methods are organized by increasing labor costs.

\begin{tabular}{|c|c|c|c|c|}
\hline Method & Desired relative precision & Direct samples & Indirect samples & Labor cost (h) \\
\hline Radiometer & $5 \%$ & 150 & 499 & 266.7 \\
\hline Point frame $\times$ height & $5 \%$ & 60 & 269 & 291.1 \\
\hline Point frame (functional group) & $5 \%$ & 164 & 256 & 438.0 \\
\hline Point frame (total hits) & $5 \%$ & 207 & 198 & 442.7 \\
\hline Radiometer & $10 \%$ & 38 & 125 & 66.7 \\
\hline Point frame $\times$ height & $10 \%$ & 15 & 67 & 72.8 \\
\hline Point frame (by functional group) & $10 \%$ & 41 & 64 & 109.5 \\
\hline Point frame (total hits) & $10 \%$ & 52 & 50 & 110.7 \\
\hline Radiometer & $20 \%$ & 9 & 31 & 16.7 \\
\hline Point frame $\times$ height & $20 \%$ & 4 & 17 & 18.2 \\
\hline Point frame (functional group) & $20 \%$ & 10 & 16 & 27.4 \\
\hline Point frame (total hits) & $20 \%$ & 13 & 12 & 27.7 \\
\hline Radiometer & $30 \%$ & 4 & 14 & 7.4 \\
\hline Point frame $\times$ height & $30 \%$ & 2 & 7 & 8.1 \\
\hline Point frame (functional group) & $30 \%$ & 5 & 7 & 12.2 \\
\hline Point frame (total hits) & $30 \%$ & 6 & 6 & 12.3 \\
\hline Radiometer & $40 \%$ & 2 & 8 & 4.2 \\
\hline Point frame $\times$ height & $40 \%$ & 1 & 4 & 4.5 \\
\hline Point frame (functional group) & $40 \%$ & 3 & 4 & 6.8 \\
\hline Point frame (total hits) & $40 \%$ & 3 & 3 & 6.9 \\
\hline Radiometer & $50 \%$ & 2 & 5 & 2.7 \\
\hline Point frame $\times$ height & $50 \%$ & 1 & 3 & 2.9 \\
\hline Point frame (functional group) & $50 \%$ & 2 & 3 & 4.4 \\
\hline Point frame (total hits) & $50 \%$ & 2 & 2 & 4.4 \\
\hline
\end{tabular}

Table 6. Number of direct and indirect samples required and labor cost (in hours) to achieve a desired relative precision for the mixed grass prairie site. For each desired precision, methods are organized by increasing labor costs.

\begin{tabular}{|c|c|c|c|c|}
\hline Method & Desired relative precision & Direct samples & Indirect samples & Labor cost (h) \\
\hline Radiometer & $5 \%$ & 237 & 1449 & 830.8 \\
\hline Point frame $\times$ height & $5 \%$ & 113 & 586 & 924.4 \\
\hline Point frame (total hits) & $5 \%$ & 140 & 631 & 944.3 \\
\hline Point frame (functional group) & $5 \%$ & 120 & 591 & 951.1 \\
\hline Radiometer & $10 \%$ & 59 & 362 & 207.7 \\
\hline Point frame $\times$ height & $10 \%$ & 28 & 147 & 231.1 \\
\hline Point frame (total hits) & $10 \%$ & 35 & 158 & 236.1 \\
\hline Point frame (functional group) & $10 \%$ & 30 & 148 & 237.8 \\
\hline Radiometer & $20 \%$ & 15 & 91 & 51.9 \\
\hline Point frame $\times$ height & $20 \%$ & 7 & 37 & 57.8 \\
\hline Point frame (total hits) & $20 \%$ & 9 & 39 & 59.0 \\
\hline Point frame (functional group) & $20 \%$ & 8 & 37 & 59.5 \\
\hline Radiometer & $30 \%$ & 7 & 40 & 23.1 \\
\hline Point frame $\times$ height & $30 \%$ & 3 & 16 & 25.7 \\
\hline Point frame (total hits) & $30 \%$ & 4 & 18 & 26.2 \\
\hline Point frame (functional group) & $30 \%$ & 3 & 16 & 26.4 \\
\hline Radiometer & $40 \%$ & 4 & 23 & 13.0 \\
\hline Point frame $\times$ height & $40 \%$ & 2 & 9 & 14.4 \\
\hline Point frame (total hits) & $40 \%$ & 2 & 10 & 14.7 \\
\hline Point frame (functional group) & $40 \%$ & 2 & 9 & 14.8 \\
\hline Radiometer & $50 \%$ & 2 & 15 & 8.3 \\
\hline Point frame $\times$ height & $50 \%$ & 1 & 6 & 9.3 \\
\hline Point frame (total hits) & $50 \%$ & 1 & 6 & 9.5 \\
\hline Point frame (functional group) & $50 \%$ & 1 & 6 & 9.5 \\
\hline
\end{tabular}


could have lower variance. The methods used in the recent work of Przeszlowska et al. (2009) could explain the stronger relationship between reflectance and greenness that they found. They used a different radiometer and reflectance indices than we did, included three sample dates in their regression equation, and periodically referenced the radiometer to a standard reflectance panel. They found that reflectance of only the RED band or the soil adjusted vegetation index explained more of the variability in greenness than NDVI (similar to our formula for GI). All of these details increase sampling time (and therefore labor costs) but have the potential for improving accuracy of this method. Our radiometer method and optimization analysis provide the reader with a simple, straightforward method to nondestructively estimate ANPP using only one sample date.

Although the point frame method most accurately predicted ANPP at both sites, our cost optimization analysis demonstrated that it is not necessarily the best method for researchers and land managers who would like to optimize precision yet minimize labor costs. At both study sites, we found that the radiometer, although less accurate, could achieve a desired precision for lower labor costs than the point frame. This is due to the better spatial coverage the radiometer can attain because of its much lower labor costs $(5 \mathrm{~min}$ for the radiometer vs. $90 \mathrm{~min}$ or $180 \mathrm{~min}$ for the point frame $\times$ height methods at the shortgrass steppe and mixed grass prairie, respectively). Similarly, Przeszlowska et al. (2009) conducted a simple costefficiency analysis (no incorporation of method accuracies) and found their radiometer method to be most cost effective.

\section{IMPLICATIONS}

The radiometer and point frame methods will be a useful tool for grassland ecologists and rangeland managers who desire fast, nondestructive estimates of aboveground net primary production. The methods will require calibrations at each site as the predictive models we produced did not contain similar variable coefficients. Although we did not measure temporal variation in the model predictions between sites, it is likely that the methods will require annual calibrations as well (P. B. Adler, unpublished data, 2010). Even with the required calibrations, the proposed techniques can greatly increase sample size and provide accurate estimates of ANPP in long-term grassland studies where destructive harvesting is impractical or impossible.

\section{ACKNOWLEDGMENTS}

We thank M. Biondini and two anonymous reviewers for their helpful comments.

\section{LITERATURE CITED}

Aase, J. K., A. B. Frank, and R. J. Lorenz. 1987. Radiometric reflectance measurements of northern Great Plains rangeland and crested wheatgrass pastures. Journal of Range Management 40:299-302.

AHMED, J., AND C. D. Bonham. 1982. Optimum allocation in multivariate double sampling for biomass estimation. Journal of Range Management 35(6):777-779.
Albertson, F. W., and G. W. Tomanek. 1965. Vegetation changes during a 30-year period in grassland communities near Hays, Kansas. Ecology 46:714-720.

Asrar, G., E. T. Kanemasu, R. D. Jackson, and P. J. Pinter, Jr. 1985. Estimation of total above-ground phytomass production using remotely sensed data. Remote Sensing of Environment 17:211-220.

Canton, B. P., D. C. Navarez, and A. E. Cope. 2004. Comparing two technologies for quantifying rice plant cover in breeding nurseries. International Rice Research Notes 29:70-71.

Cochran, W. G. 1963. Sampling techniques. New York, NY, USA: John Wiley \& Sons. 413 p.

Fletcher, J. E., And M. E. Robinson. 1956. A capacitance meter for estimating forage weight. Journal of Range Management 9:96-97.

Frank, D. A., and S. J. McNaughton. 1990. Aboveground biomass estimation with the canopy intercept method: a plant growth form caveat. Oikos 57:57-60.

Jonasson, S. 1988. Evaluation of the point intercept method for the estimation of plant biomass. Oikos 52:101-106.

Lauenroth, W., A. Wade, M. Williamson, B. Ross, S. Kumar, and D. Cariveau. 2006. Uncertainty in calculations of net primary production for grasslands. Ecosystems 9:843-851.

LauenRoth, W. K. 2008. Vegetation of the shortgrass steppe. In: W. K. Lauenroth and I. C. Burke [EDS.]. Ecology of the shortgrass steppe. New York, NY, USA: Oxford University Press. p. 70-83.

Lauenroth, W. K., H. W. Hunt, D. M. Swift, and J. S. Singh. 1986. Estimating aboveground net primary production in grasslands: a simulation approach. Ecological Modeling 33:297-314.

Limb, R. F., K. R. Hickman, D. M. Engle, J. E. Norland, and S. D. Fuhlendorf. 2007. Digital photography: reduced investigator variation in visual obstruction measurements for southern tallgrass prairie. Rangeland Ecology \& Management 60:548-552.

McNaughton, S. J., M. Oesterheld, D. A. Frank, and K. J. Williams. 1989. Ecosystemlevel patterns of primary productivity and herbivory in terrestrial habitats. Nature 341:142-144.

Paruelo, J. M., W. K. Lauenroth, and P. A. Roset. 2000. Estimating aboveground plant biomass using a photographic technique. Journal of Range Management 53:190-193.

Przeszlowska, A., M. J. Trlica, and M. A. Weltz. 2009. Near-ground remote sensing of green area index on the shortgrass prairie. Rangeland Ecology \& Management 59:422-430.

R Development Core Team. 2009. R: a language and environment for statistical computing. Vienna, Austria: R Foundation for Statistical Computing. Available at: http://www.r-project.org. Accessed 6 August 2011.

Sala, O. E., and A. T. Austin. 2000. Methods of estimating aboveground net primary productivity. In: 0. E. Sala, R. B. Jackson, H. A. Mooney, and R. W. Howarth [EDS.]. Methods in ecosystem science. New York, NY, USA: Springer. p. 31-43.

SelLeRS, P. J. 1987. Canopy reflectance, photosynthesis, and transpiration, II. The role of biophysics in the linearity of their interdependence. Remote Sensing of Environment 21:143-183.

Sellers, P. J., J. A. Berry, G. J. Collatz, C. B. Field, and F. G. Hall. 1992. Canopy reflectance, photosynthesis, and transpiration. III. A reanalysis using improved leaf models and a new canopy integration scheme. Remote Sensing of Environment 42:187-216.

Singh, J. S., W. K. Lauenroth, and R. K. Steinhorst. 1975. Review and assessment of various techniques for estimating net aerial primary production in grasslands from harvest data. Botanical Review 41:181-232.

Tomasel, F. G., J. M. Paruelo, G. Abras, V. Ballarin, and E. Moler. 2001. A chromaticity-based technique for estimation of above-ground plant biomass. Applied Vegetation Science 4:207-212.

Tucker, C. J., L. D. Miller, and R. T. Pearson. 1975. Shortgrass prairie spectral measurements. Photogrammetric Engineering and Remote Sensing 41: 1157-1162.

Vickery, P. J., I. L. Bennett, and G. R. Nicol. 1980. An improved electronic capacitance meter for estimating herbage mass. Grass \& Forage Science $35: 247-252$. 


\section{APPENDIX}

Using the notation of Ahmed and Bonham (1982), the cost of double sampling is

$$
C=n c_{n}+n^{\prime} c_{n}^{\prime}
$$

where $C=$ total cost of double sampling, $c_{n}=$ cost of obtaining one direct sample, $c_{n}{ }^{\prime}=$ cost of obtaining one indirect sample, $n=$ number of direct samples, and $n^{\prime}=$ number of indirect samples.

For a fixed cost $C$, optimal allocation (with minimum estimate variance) is achieved when

$$
\frac{n^{\prime}}{n}=\frac{\sqrt{V_{n}{ }^{\prime} c_{n}}}{\sqrt{V_{n} c_{n}{ }^{\prime}}},
$$

where $V_{n}=\left(S_{y}^{2}\right)\left(1-\rho^{2}\right), V_{n}{ }^{\prime}=\rho^{2} S_{y}^{2}, \rho^{2}=$ coefficient of correlation between $y$ (biomass) and $x$ (indirect method), and $S_{y}^{2}=$ standard deviation of $y$ (biomass).
Ahmed and Bonham (1982) showed that we can input the optimal allocation ratio calculated in equation 2 into the following formula with a desired variance $(V)$ to calculate the number of direct and indirect samples needed:

$$
\widehat{V}=\frac{V_{n}}{n}+\frac{V_{n}^{\prime}}{n^{\prime}} .
$$

Based on this variance, sampling effort can be adjusted to achieve desired relative precision, where $\widehat{V}$ is the desired precision. For example, at our mixed grass prairie site, our $y$ estimate was 113.2 . If we desired a $20 \%$ relative precision (which we defined based on half the width of the $95 \%$ confidence interval [ $\pm \sim 2 \mathrm{SD}$ ], as a percentage of the estimate itself) using the radiometer method, then the $95 \%$ CI for the estimate would be $113.2 \pm 22.64(\sim 2$ SD). The SD would be 11.32 , and therefore $\widehat{V}$, the variance, would be $11.32^{2}$, or 128.14 . Once $n$ and $n^{\prime}$ are calculated using equation 3 , they can be used to calculate total sampling cost using equation 1. 